RESEARCH ARTICLE

\title{
TNAU coconut ALR 3 - a promising mite tolerant tendernut variety
}

Geethanjali. S*1, Kumar. $\mathbf{M}^{2}$, Rajakumar. $D^{3}$, Sivakumar. $\mathbf{V}^{\mathbf{4}}$ and Rajamanickam. $\mathbf{K}^{\mathbf{5}}$

${ }^{* 1}$ Department of Genetics and Plant Breeding, CPBG, Tamil Nadu Agricultural University, Coimbatore - 641003

${ }^{2}$ Tamil Nadu Agricultural University, Coimbatore - 641003

${ }^{3}$ Department of Agronomy, AC \& RI, Killikulam, Thoothukudi - 628252

${ }^{4}$ Coconut Research Station, Tamil Nadu Agricultural University, Aliyarnagar - 642101

${ }^{5}$ Directorate of ODL, Tamil Nadu Agricultural University, Coimbatore - 641003

\begin{abstract}
Coconut water is considered as nature's gift to mankind due to its health benefits. The steady demand for tender coconut is currently met from a local dwarf from Kerala, viz., Chowghat Orange Dwarf (COD). However, there is a need for diversification of genotypes. Based on a 20-year-old germplasm evaluation trial conducted at Coconut Research Station (CRS), Aliyarnagar, a selection from Kenthali Dwarf (KTD) has been identified as a promising genotype exclusively for tender nut purpose. It has been released as TNAU coconut ALR 3. The selection is an early flowering genotype that comes to flowering from the third year onwards. The average yield potential is 86 nuts per palm per annum from the stabilized bearing period onwards, with a maximum yield potential of 121 nuts per palm per annum. This accounts for $34.1 \%$ and $37.9 \%$ increase in yield over COD and MYD. Tender nut water analysis revealed that the genotype possessed $5.2 \%$ soluble sugars with a high potassium level (190.21) compared to COD and MYD. The variety is recommended for irrigated belts of Tamil Nadu.
\end{abstract}

Keywords: Coconut ; TNAU ALR 3 tender nut variety

\section{INTRODUCTION}

Coconut is an economically important oil seed crop of the tropics. It is generally known as the 'tree of life' due to the multipurpose financial benefits derived from each and every part of the palm contributing to the sustained livelihood of its growers (Sivakumar et al., 2021). In India, the area under coconut cultivation has expanded vastly since the 1950's to an area of 2,150 thousand hectares with a total production of 21,288 million nuts and productivity of 9,897 nuts per ha (Sivakumar et al., 2020). Tamil Nadu is the leading producer of coconut in India, next to Kerala, with an area of 4.37 thousand hectares, production of 5,370 million nuts and productivity of 12,291 nuts per ha (CDB 2018-19). Although coconut has been traditionally cultivated for copra, oil and culinary purposes, the highly fluctuating prices for copra and coconut oil have made the coconut growers to diversify their coconut cultivation for tender nut purposes. Tender coconut water comes as an untouched natural drink, highly rich in sugars, minerals, vitamins, amino acids and phytohormones (Jean et al., 2009). There exists a substantial shift towards tender coconut water as a natural drink due to its health benefits, which has *Corresponding author's e-mail: geethanjalitnau@yahoo.com contributed to the sharp and steady increase in the demand. Generally, 6-7 months old nuts harvested from elite talls, dwarfs and hybrids are sold as tender nuts. There is a strong consumer preference for dwarf genotypes since they are exclusively suitable for tender nut purposes. The current demand for tender coconut is currently met from a local dwarf from Kerala, viz., Chowghat Orange Dwarf (COD). However, this variety is susceptible to mite infestation. Hence there is a need to develop varieties suitable for tender nut purposes coupled with mite resistance to improve its market value. With this objective, a selection from Kenthali dwarf has been made and released as TNAU coconut ALR 3 during 2012, based on 20-year-old germplasm evaluation trial.

\section{MATERIAL AND METHODS}

TNAU coconut ALR 3 is a selection from Kenthali dwarf. The accession was received from Central Plantation and Crop Research Institute (CPCRI), Kasaragod, during 1988, as a germplasm material along with 15 other indigenous and exotic accessions. The material was planted at Coconut Research Station, Aliyarnagar and evaluated for

$$
107 \mid 10-12 \text { | } 1
$$


20 years. Palm morphology, floral biology, harvest data and nut characters were documented in the proforma envisaged in the coconut Descriptors (2000). Chemical constituents of tender nut water extracted from 6-7-month-old nuts were tested along with elite dwarfs, talls, and hybrids as checks at the Post Harvest Technology Centre, TNAU, Coimbatore. The nuts of TNAU coconut ALR 3 and checks viz.,
Chowghat Orange Dwarf (COD) and Malayan yellow dwarf (MYD) were screened for eriophyid mite damage by recording the percentage of nut area infestation as described by Julia and Mariau (1979). In addition, morphological features, namely bract arrangement and length to circumference ratio in the nuts, were also recorded.

\section{Table 1. Salient palm morphological characters of TNAU Coconut ALR 3}

\begin{tabular}{|c|c|c|c|c|}
\hline Category & : & Dwarf & Length of inflorescence (cm) & \\
\hline Crown shape & : & Circular & Length of spikelet bearing portion (cm) & \\
\hline Plant height $(\mathrm{cm})$ & : & 1120 & Length of stalk $(\mathrm{cm})$ & \\
\hline Total number of leaves & : & $30-35$ & Number of spikelets/ inflorescence & \\
\hline Length of petiole (cm) & $:$ & 100.9 & Number of female flowers & \\
\hline Petiole colour & $:$ & Deep orange & Number of inflorescences / year & \\
\hline Length of leaflet bearing portion (cm) & : & 473.3 & Length of male phase (days) & \\
\hline Breadth of leaflet (cm) & : & 4.8 & Length of female phase (days) & \\
\hline $\begin{array}{l}\text { Girth of the trunk }(\mathrm{cm}) \text { (1m above } \\
\text { ground level) }\end{array}$ & : & 75 & $\begin{array}{l}\text { Gap between male and female phases } \\
\text { (days) }\end{array}$ & \\
\hline Number of leaf scars in $1 \mathrm{~m}$ length & : & 21 & Intra-spadix overlapping & \\
\hline Length of 10 internodes (cm) & : & 54 & Inter-spadix overlapping & \\
\hline Pollination group & $:$ & Self pollinated & Colour of fruit & \\
\hline Age at first flowering (months) & : & 29 & Shape of the fruit & \\
\hline
\end{tabular}

\section{RESULTS AND DISCUSSION}

TNAU Coconut ALR 3 is an early flowering dwarf and comes to bearing from the third year onwards. It is highly suitable for irrigated coconut belts of Tamil Nadu and serves as a promising genotype exclusively for tender nut purposes. The salient features and nut characters are provided in Tables 1 and 2. On an average, TNAU coconut ALR 3 has a yield potential of 86 nuts per palm per annum

from the stabilized bearing period onwards with a maximum yield potential up to 121 nuts per palm per annum. This accounts for 34.1 and 37.9 percent yield increase over the popular tender nut genotypes viz., Chowghat Orange Dwarf (COD) and Malayan Yellow Dwarf (MYD), respectively (Table 2). It produces approximately 2.15 tonnes of copra/ha, and 5195 nuts of TNAU coconut ALR 3 is required to produce one tonne of copra.

Table 2. Nut characters of Kenthali dwarf

\begin{tabular}{|c|c|c|c|c|c|c|c|c|c|c|c|}
\hline $\begin{array}{l}\text { Name of the } \\
\text { genotype }\end{array}$ & $\begin{array}{l}\text { Nut yield/ } \\
\text { annum }\end{array}$ & $\begin{array}{c}\text { Fruit } \\
\text { weight (kg) }\end{array}$ & $\begin{array}{c}\text { Fruit } \\
\text { length }(\mathbf{c m})\end{array}$ & $\begin{array}{c}\text { Fruit } \\
\text { breadth } \\
(\mathrm{cm})\end{array}$ & $\begin{array}{c}\text { Nut weight } \\
\text { (g) }\end{array}$ & $\begin{array}{c}\text { Split nut } \\
\text { weight (g) }\end{array}$ & $\begin{array}{c}\text { Kernel } \\
\text { weight (g) }\end{array}$ & $\begin{array}{c}\text { Kernel } \\
\text { thickness } \\
\text { (cm) }\end{array}$ & $\begin{array}{c}\text { Husk } \\
\text { thickness } \\
\text { (cm) }\end{array}$ & $\begin{array}{c}\text { Tender } \\
\text { nut water } \\
\text { (ml) }\end{array}$ & $\begin{array}{l}\text { Copra } \\
\text { yield per } \\
\text { nut (g) }\end{array}$ \\
\hline TNAU & & & & & & & & & & & \\
\hline $\begin{array}{l}\text { coconut } \\
\text { ALR } 3\end{array}$ & 86 & 1.69 & 23.5 & 16.3 & 920.0 & 610.0 & 347.5 & 1.1 & 2.0 & 420 & 192.5 \\
\hline COD & 74 & 1.22 & 22.8 & 16.5 & 670.0 & 462.5 & 242.5 & 0.8 & 1.6 & 375 & 145.0 \\
\hline MYD & 70 & 1.53 & 23.5 & 17.3 & 667.5 & 462.5 & 297.5 & 1.2 & 3.0 & 275 & 152.5 \\
\hline Mean & 76.7 & 1.5 & 23.3 & 16.7 & 752.5 & 511.7 & 295.8 & 1.0 & 2.2 & 356.7 & 163.3 \\
\hline SD & 8.3 & 0.2 & 0.4 & 0.5 & 145.1 & 85.2 & 52.5 & 0.2 & 0.7 & 74.2 & 25.5 \\
\hline CV & 10.9 & 16.1 & 1.7 & 3.2 & 19.3 & 16.6 & 17.8 & 20.1 & 32.8 & 20.8 & 15.6 \\
\hline
\end{tabular}

A coconut genotype is considered suitable for tender nut purposes when it has a water content of at least 200-350 ml, with a total sugar of about $4-5 \%$ (Sunil et al., 2020). The variety TNAU coconut ALR 3 produces bright orange coloured nuts with sweet tender nut water measuring $420 \mathrm{~mL}$ on an average. The tender nut water is rich in total soluble sugars (5.2 percent) and potassium (190.20 mg per 100mL) (Table 3).

$107 \mid 10-12$ | 2 
A genotype is best identified for tender nut purpose based on the quantity and quality of tender nut water and to some extent, based on nut colour. Some varieties considered suitable for the production of tender nuts include Chowghat Orange Dwarf, Malayian Yellow Dwarf, Malayian Orange Dwarf, Malayian Green Dwarf and Gangabondam (Rethinam and Kumar, 2001). The major constituents of tender nut water include sugars and minerals. Among the sugars, tender nut water is mostly comprised of reducing sugars viz., glucose and fructose. As the nut matures, the proportion of reducing sugars decreases and the non-reducing sugars, namely sucrose increase. A comparative analysis of tender nut water constituents of TNAU coconut ALR 3 with MYD and COD showed that the reducing sugar and non-reducing sugars was nominal in the 6-7-monthold nuts of TNAU coconut ALR 3 to give a sweet taste as evidenced in the organoleptic test. While MYD was known to have a higher amount of sugar content (5.9\%), the total water content was relatively lower than TNAU coconut ALR 3 (Table 3).

Table 3. Comparative analysis of tender nut water quality parameters in coconut genotypes

\begin{tabular}{|c|c|c|c|c|c|c|c|c|}
\hline $\begin{array}{l}\text { S. } \\
\text { No }\end{array}$ & Genotypes & $\begin{array}{l}\text { Volume of } \\
\text { water (ml) }\end{array}$ & $\begin{array}{c}\text { Total } \\
\text { soluble } \\
\text { solids (Brix) }\end{array}$ & $\begin{array}{c}\text { Total } \\
\text { soluble } \\
\text { sugars (\%) }\end{array}$ & $\begin{array}{l}\text { Reducing } \\
\text { sugars (\%) }\end{array}$ & $\begin{array}{c}\text { Non } \\
\text { reducing } \\
\text { sugars (\%) }\end{array}$ & $\begin{array}{c}\text { Sodium } \\
(\mathrm{mg} / 100 \mathrm{ml})\end{array}$ & $\begin{array}{l}\text { Potassium } \\
\text { (mg/100ml) }\end{array}$ \\
\hline \multicolumn{9}{|c|}{ Dwarf varieties } \\
\hline 1. & $\begin{array}{l}\text { TNAU coconut } \\
\text { ALR } 3\end{array}$ & 420.00 & 5.60 & 5.20 & 4.60 & 0.60 & 8.65 & 190.20 \\
\hline 2. & COD & 375.00 & 5.20 & 4.00 & 3.70 & 0.30 & 12.86 & 81.30 \\
\hline 3. & MYD & 275.00 & 6.20 & 5.90 & 5.50 & 0.40 & 24.88 & 110.30 \\
\hline \multicolumn{9}{|c|}{ Tall varieties } \\
\hline 4. & WCT & 640.00 & 4.60 & 4.20 & 3.80 & 0.40 & 13.55 & 300.00 \\
\hline 5. & ALR (CN) 1 & 350.00 & 4.80 & 4.50 & 4.30 & 0.20 & 13.08 & 269.50 \\
\hline 6. & ECT & 460.00 & 5.00 & 4.60 & 4.20 & 0.40 & 10.68 & 284.20 \\
\hline \multicolumn{9}{|c|}{ Hybrids } \\
\hline 7. & VHC 2 & 510.00 & 4.80 & 4.60 & 4.50 & 0.10 & 13.12 & 208.20 \\
\hline \multirow[t]{4}{*}{8.} & Dee Jay & 400.00 & 5.00 & 4.80 & 4.40 & 0.40 & 19.11 & 250.20 \\
\hline & Mean & 428.75 & 5.15 & 4.73 & 4.38 & 0.35 & 14.49 & 211.74 \\
\hline & SEd & 14.81 & 0.22 & 0.08 & 0.15 & 0.01 & 0.68 & 7.53 \\
\hline & $C D(p=0.05)$ & 32.00 & 0.48 & 0.17 & 0.33 & 0.02 & 1.47 & 16.32 \\
\hline
\end{tabular}

Next to sugars, coconut water is rich in minerals, particularly potassium. The accumulation of potassium content in the nuts is also influenced by potassium application in the soil. It has been reported that $78 \%$ of the potassium is removed from the coconut palm when the nuts are harvested (Khan et al., 2001). Tender coconut analysis of coconut dwarfs showed that TNAU coconut ALR 3 possessed a higher potassium level than the local dwarf checks (Table 3). A higher level of potassium is a desirable attribute since it is an essential positive ion that regulates heartbeat and muscle function and plays a potential role in increasing urinary output (Hegde, 2011). Among the dwarfs, TNAU coconut ALR 3 also recorded significantly low levels of sodium. Lesser sodium level may result in reduced heart problems and avoid dehydration. Considering the overall performance for the various parameters viz., nut yield, colour of the nut, quantity of tender nut water, richness of sugars and minerals, particularly potassium, TNAU coconut ALR 3 was found to be superior to the local checks and thus may serve as an elite dwarf exclusively suitable for tender nut purpose.

Table 4. Reaction of tendernut coconut cultivars to Eriophyid damage

\begin{tabular}{crrrr}
\hline S. No & Genotypes & Nut area damage (\%) & Length circumference ratio & Mean damage grade \\
\hline 1. & TNAU coconut ALR 3 & 6.5 & $1: 1.17$ & 1.25 \\
2. & COD & 28.0 & $1: 1.09$ & 2.20 \\
3. & MYD & 52.65 & $1: 1.04$ & 3.95 \\
\hline
\end{tabular}


Although there is a steady demand for tender nuts, mite infestation on the nuts is a severe problem, which reduces consumer preference. Nut damage is caused by the coconut perianth mite Aceria guerreronis Keifer (Ramarethinam and Loganathan, 2000). These mites inhabit the floral bracts and the tender portion of the nuts covered by the perianth (Moore and Alexander, 1987). The mites suck the sap resulting in brownish patches, warting and longitudinal fissures on the nut surface, which reduces the market value of the economic product. Although IPM measures are available to control mite infestation, the success rate is poor due to the difficulties encountered in the spray applications of pesticides and bioagents. This warrants the need to explore the inherent genetic resistance contributed due to components such as antixenosis, antibiosis and tolerance in the host plant. The level of tolerance to mite infestation was studied in TNAU coconut ALR 3 along with COD and MYD, as checks maintained under natural field conditions at Coconut Research Station, Aliyarnagar. TNAU coconut ALR 3 recorded the least damage of $6.5 \%$, while the checks COD and MYD recorded 28 and $52.65 \%$, respectively (Table 4). Eriophyid mite tolerance in Kenthali in the British Solomon Islands had also been reported (Ramaraju et al., 2000; Kannaiyan et al., 2002). A morphological analysis of the fruit revealed that type II arrangement of bracts with a tight perianth could serve as a morphological barrier for mite entry in TNAU Coconut ALR 3, thereby contributing to its tolerance. Also, a preliminary study showed that the higher length to circumference ratio in the fruit could be positively associated with eriophyid mite tolerance (Unpublished data).

\section{CONCLUSION}

TNAU coconut ALR 3, an early flowering dwarf, is a promising cultivar for tender nut purposes and suitable for the irrigated coconut growing regions of Tamil Nadu. Due to the superiority of this variety as a tender nut genotype coupled with mite tolerance, nucleus seed gardens have been established at Coconut Research Station, Aliyarnagar to produce quality planting materials for farmers. The genotype is also currently utilized in the breeding programme along with elite talls such as West Coast Tall and Etamozhi tall for synthesis and evaluation of promising D x T hybrids.

\section{Funding and Acknowledgment}

The authors are highly thankful to Tamil Nadu Agricultural University for financial and technical support provided to conduct this study at Coconut Research Station, Aliyarnagar.

\section{Ethics statement}

No specific permits were required for the described field studies because no human or animal subjects were involved in this research.

\section{Originality and plagiarism}

We assure that we have written and submitted only entirely original works.

\section{Consent for publication}

All the authors agreed to publish this research article.

\section{Competing interests}

There were no conflict of interest in the publication of this content

\section{Data availability}

All the data of this manuscript are included in the MS. No separate external data source is required. If anything is required from the MS, certainly, this will be extended by communicating with the corresponding author through corresponding official mail; geethanjalitnau@yahoo.com.

\section{Author contributions}

Research grant- SG,MK; Idea conceptualizationSG, Experiments-SG, MK, KR, DR; Guidance-SG, MK: Writing original draft-SG,DR; Writing- reviewing \& editing-SG, VS

\section{REFERENCES}

Coconut Development Board CDB (Online) 2018-19. Available https://coconutboard.nic.in/ Statistics. aspx.

Hegde, B. M. 2011. Tender coconut water, a divine health elixir. Indian Coconut Journal., 54 (8):4-5.

Julia, J. F. and Mariau, D. 1979. New research on the coconut mite, Eriophyes guerreronis (K.) in the Ivory coast. Oleagineux., 34 :181-189.

Kannaiyan, S., Rabindra, R. J., Ramaraju, K. and Doraiswamy, S. 2002, Integrated Management of Eriophyid Mite on Coconut. Tamil Nadu Agricultural University, Coimbatore, pp. 1-76.

Moore, D. and Alexander, L. 1987. Aspects of migration and colonization of the coconut palm by the coconut mite, Eriophyes guerreronis Keifer (Acari:Eriophyidae). Bulletin of Entomological Research., 77: 641-650.

Ramaraju, K., Natarajan, K., Sundarababu, P. C. and Palanisamy, S. 2000. Studies on coconut eriophyid mite, A. guerreronis K. in Tamil Nadu, India. In: International Workshop on Coconut Eriophyid Mite held at CRI, Srilanka, Jan 5-7, 2000, pp. 8-9.

Ramarethinam, S. and Loganathan, S. 2000. Biology of Aceria guerreronis Keifer(Acari: Eriophyoidea; Eriophyidae) - A perianth mite infesting coconut groves in India. Pestology., 24 (6): 6-9.

Rethinam, P., Kumar TBN. Tender coconut-an overview, Indian Coconut Journal., 2001; 32:2-22

Sivakumar, V., Subramanian, A., Geethanjali, S., Praneetha, S. and Maheswarappa, H. P. 2020. Assessment of genetic variability for growth, floral, yield and its 
component traits in coconut (Cocos nucifera L.). Electronic Journal of Plant Breeding., 11(3):809-813.

Sivakumar, V., Geethanjali, S., Subramanian, A., Praneetha, S., Maheswarappa, H. P. and Rajkumar, D. 2021. Correlation and path coefficient studies for fruit component traits in coconut (Cocos nucifera L.) hybrids. Electronic Journal of Plant Breeding., 12(1):224 - 227.

Khan, H.A., A.K. Upadhyay, and C. Palaniswami. 2001. Potassium in Plantation Crops. Proc. Intl. Symp. on
$\mathrm{K}$ in Nutrient Management for Sustainable Crop Production in India. New Delhi, India, 3-5 Dec. 2001. p. 467-497.

Sunil, L., Prakruthi Appaiah., Prashant Kumar, P.K. and Gopala Krishna, A. G. 2020. Coconut water- Nature's miracle health drink: Chemistry, Health Benefits, Packaging, Storage and Technologies: A Review. Indian Coconut Journal. Pp17-25 